\section{SITE RECORDS OFYELLOW-THROATED BULBUL PYCNONOTUS XANTHOLAEMUS (JERDON, 1844) IN THE NALLAMALA HILLS, EASTERN GHATS, ANDHRA PRADESH, INDIA}

\section{Srinivasulu}

Research Associate (Wildlife), Wildlife Biology Section, Department of Zoology, Osmania University, Hyderabad, Andhra Pradesh 500007, India

Email:masawa@hd2.dot.net.in

The Yellow-throated Bulbul Pycnonotus xantholaemus (Jerdon, $1844)$ is a threatened and endemic species restricted in distribution to southern India (Birdlife International, 2001). It has been reported from different localities of Eastern Ghats in Andhra Pradesh and Tamil Nadu (Allen, 1908; Karthikeyan, 1995; Subramanya \& Prasad, 1996; Subramanya et al., 1990; Subramanya et al., 1995; Rao, 1995; Kumar, 1999; Pittie 1999a, b, 2001b), associated hill complexes in Karnataka (Wilson \& Editors, 1908; Subramanya et al., 1991; Karthikeyan et al., 1995; Subramanya et al., 1995; Venkataswamappa \& Chaitra, 1999; Pittie, 2001a) and also from Western Ghats in Tamil Nadu (Kannan, 1992) and Kerala (Ali \& Ripley, 1987). Through this note I am presenting site records of the Yellow-throated Bulbul in the Nallamala Hills, Eastern Ghats, Andhra Pradesh.

I have been documenting the faunal diversity of the Nallamala Hills $\left(15^{\circ} 20^{\prime}-16^{0} 31^{\prime} \mathrm{N}\right.$ and $\left.78^{0} 30^{\prime}-80^{\circ} 10^{\prime} \mathrm{E}\right)$ in the Eastern Ghats of Andhra Pradesh (Srinivasulu \& Nagulu, 2002) since 1995. The Nallamala is a group of low hill ranges in the central part of Eastern Ghats encompassing an area of about $7,640 \mathrm{~km}^{2}$. The vegetation is typically of southern tropical dry deciduous and southern tropical moist deciduous forest types intermingled with scrub (Champion \& Seth, 1968).

The Yellow-throated Bulbul was first recorded from the Nallamalas between 12-14 July 1997 when it was heard several times in the valleys between Potharajupenta and Rollapenta on the southern side of the Nagarjunasagar -Srisailam Tiger Reserve $\left(15^{0} 53^{\prime}-16^{0} 42^{\prime} \mathrm{N}\right.$ and $\left.78^{0} 30^{\prime}-79^{0} 28^{\prime} \mathrm{E}\right)$. On 14 July 1997 a pair of birds were sighted on Anogeissus latifolia tree near Rollapenta. During a later survey on 21 November 1997, a single individual was again sighted on Ficus bengalensis tree near Potharajupenta. The present sightings constitute the first report of this species from the Nallamala Hills as earlier surveys (Ali, 1933a,b,c; 1934a,b; Bhushan 1994; Rao et al., 1997; Taher, 1999) failed to record it. Furthermore, later records of this species $140 \mathrm{~km}$ north in the Umamaheshwaram region near Mananur (Kumar, 1999; Pittie, 1999a) indicates that this species could well be sighted elsewhere in the Nallamala Hills. I totally agree with Karthikeyan et al. (1995) who opined that the Yellowthroated Bulbul has a disjunct but a wider distribution than hitherto accepted, and hence appeal to researchers undertaking ornithological expeditions in the Eastern and Western Ghats to pay more attention towards this endemic and threatened bird.

\section{Acknowledgments}

I thank the Head of the Department of Zoology, Dr. V. Nagulu, Osmania University for permitting me to carry out the present study and for encouragement. Thanks are also due to the Chief Wildlife Warden, Andhra Pradesh Forest Department; Project Director, Nagarjunasagar-Srisailam Tiger Reserve for permission; Mr. K. Thulsi Rao, ACF (Biodiversity) NSTR for his hospitality; and Mr. Aasheesh Pittie of Birdwatchers' Society of Andhra Pradesh for information. Financial assistance from the CSIR, New Delhi is also acknowledged.

\section{References}

Ali, S. (1933a). The Hyderabad State Ornithological Survey. Part I. Journal of the Bombay Natural History Society 36(2): 356-390.

Ali, S. (1933b). The Hyderabad State Ornithological Survey. Part 2. Journal of the Bombay Natural History Society 36(3): 707-725.

Ali, S. (1933c). The Hyderabad State Ornithological Survey. Part 3. Journal of the Bombay Natural History Society 36(4): 898-919.

Ali, S. (1934a). The Hyderabad State Ornithological Survey. Part 4. Journal of the Bombay Natural History Society 37(1): 124-142.

Ali, S. (1934b). The Hyderabad State Ornithological Survey. Part 5. Journal of the Bombay Natural History Society 37(2): 425-454.

Ali, S. and S.D. Ripley (1987). Handbook of Birds of India and Pakistan. Compact Edition. Oxford University Press, New Delhi.

Allen, P.R. (1908). Notes on the Yellow-throated Bulbul Pycnonotus xantholaemus. Journal of the Bombay Natural History Society 18(4): 905-907.

Bhushan, B. (1994). Ornithology of the Eastern Ghats. Ph.D. Thesis. Submitted to University of Bombay, Bombay, 284pp. (unpublished) (Original not seen).

BirdLife International (2001). Yellow-throated Bulbul Pycnonotus xantholaemus, pp.1969-1973. In: Collar, N.J., A.V. Andrew, S. Chan, M.J. Crosby, S. Subramanya and J.A. Tobias (editors). Threatened Birds of Asia: the BirdLife International Red Data Book. Vol.2. BirdLife International, Cambridge, U.K.

Champion, H.G. and S.K Seth (1968). A Revised Survey of Forest Types of India. Government of India, New Delhi.

Kannan, R. (1992). Yellow-throated Bulbul in Anaimalai Hills. Newsletter for Birdwatchers 32(7-8): 19.

Karthikeyan, S. (1995). Notes on the occurrence of the Yellowthroated Bulbul Pycnonotus xantholaemus (Jerdon) at Shevaroys, Tamil Nadu. Journal of the Bombay Natural History Society 92(2): 266-267.

Karthikeyan, S., J.N. Prasad and T.S. Srinivasa (1995). Yellowthroated Bulbul Pycnonotus xanthotaemus (Jerdon) at Biligirirangan Hills, Karnataka. Journal of the Bombay Natural History Society 92(1): 
123-124

Kumar, S.A. (1999). Birding in Mannanur forest range, Andhra Pradesh. Newsletter for Birdwatchers 39(1): 12.

Pittie, A. (1999a). Field Trip to Uma Maheshwaram, 22 November, 1998. Pitta 93: 1-2.

Pittie, A. (1999b). Birding Notes. Pitta 5-6.

Pittie, A. (200la). Birding Notes. Pitta 121: 5-6.

Pittie, A. (2001b). Birding Notes. Pitta 124: 6-7.

Rao, T.K. (1995). Yellow-throated Bulbul - Pycnonotus xantholaemus (Jerdon) in Gingee. Blackbuck 11(1): 9-11.

Rao, V.V., V. Nagulu, M. Anjaneyulu, B. Srinivasulu, C. Srinivasulu and J.V.R. Rao (1997). Status of avifauna of Rajiv Gandhi National Park, Andhra Pradesh, India. Pavo 35(1\&2): 85-100.

Srinivasulu, C. and V. Nagulu (2002). Mammalian and avian diversity of the Nallamala Hills Andhra Pradesh. Zoos' Print Journal 17(1): 675-684.

Subramanya, S. and J.N. Prasad (1996). Yellowthroated Bulbulls at Horsley Hills. Journal of the Bombay Natural History Society 93(1): 55-58.

Submmanya, S., S. Karthikeyan and J.N. Prasad (1991). Yellowthroated Bulbul at Nandi Hills. Newsletter for Birdwatchers 31(3\&4): 7-8.

Subramanya, S., S. Karthikeyan, J.N. Prasad, T.S. Srinivasa and B. Arun (1990). A trip to Thondebhavi in search of Yellowthroated Bulbul. Newsletter for Birdwatchers 30(11\&12): 7.

Subramanya, S., J.N. Prasad and S. Karthikeyan (1995). In search of the Yellow-throated Bulbul. Sanctuary Asia 15(5): 68-70.

Taher, H. (1999). Field trip to Umamaheshwaram - 28.11.1999. Pitta 104: 1-2.

Venkataswamappa, M. and M.R. Chaitra (1999). Observations of nesting Yellow-throated Bulbuls. Oriental Bird Club Bulletin 30: 3132.

Wilson, C. L. and Editors (1908). Yellow-throated Bulbul at Bellary. Journal of the Bombay Natural History Society 18(4): 907.

Tiger Reserve, West Bengal (ca. 1200m). The place of sighting was between Buxaduar and Rupam during our bird watching trip in March 2001. Allen et al. (1996) have seen a group of this

RECENT SIGHTING OF RED-BREASTED HILL-PARTRIDGE ARBOROPHILA MANDELLII FROM BUXA TIGER RESERVE, WEST BENGAL, INDIA

\section{S. Sivakumar and Vibhu Prakash}

Bombay Natural History Society, Hornbill House, Dr. Salim Ali Chowk, S.B.Singh Road, Mumbai, Maharashtra 400023, India .

The Red-breasted Hill-Partridge ( Arborophila mandellii) is one of the nine threatened members of the suite of 19 bird species that are entirely restricted to "Eastern Himalaya Endemic Bird Area" (Birdlife International, 2001). Forest cutting, shifting agriculture and hunting for food are presumably among the deleterious pressure on population of this species (McGowan et al., 1995). The Red-breasted Hill-Partridge has recently been determined as present in three protected areas, of which Singhalila National Park in West Bengal, Mehao Wildlife Sanctuary and Dibang Valley Wildlife Sanctuary in Arunachal Pradesh are considered irreplaceably important to the longterm conservation of Galliformes in East Asia (McGowan et al., 1999).

The species was seen once during one of two visits to Buxa

Received 14 August 2002

Finally accepted 21 January 2003 partridge briefly on four occasions in the same area of the Reserve. The habitat in Buxaduar-Rupam area is very suitable for this vulnerable bird species. The ecological territory of this area extends further into Bhutan. Such a vast hilly terrain can definitely hold a good population of this vulnerable species. We think that a concerted effort to locate this species might yield positive results. There could be moderate disturbance from some nomadic human population at the Indo-Bhutan border here. However, if there is no hunting, the movement of these people cannot be considered a threat.

\section{Acknowledgements}

We express our sincere thanks to the Forest Department, West Bengal for financial support and their co-operation throughout the study period and Elbert Sangma, driver, Raja Sen and Dillip Roy, field assistance for their help and sincere involvement in field studies.

\section{References}

Allen, D., J. Anderton and K. Kazmericzak (1996). Report on an ornithological visit to Buxa Tiger Reserve, West Bengal, India, 17 February to 6 March 1992. Forktail 12: 31-48

BirdLife International (2001). Threatened Birds of Asia: The BirdLife International Red Data Book, Cambridge, U.K., BirdLife International, Part A \&B.

McGowan, P., D. Change-qing and P. Kaul (1999). Protected areas and the conservation of grouse, partridges and pheasants in East Asia. Animal Conservation 2: 93-102

McGowan, P.J.K., S.D. Dowell, J.P. Carroll and N.J. Aebischer (1995). Partridges, Quails, Francolins, Anowcocks and Guineafowl: Status Survey and Conservation Action Plan 1995-1999. Gland, Switzerland: IUCN-the World Conservation Union. 